\title{
Financial Education in Modern Ukrainian Society: Tasks and Prospects
}

\author{
Hanna Tovkanets * [0000-0002-6191-9569], Tetiana Kravchenko [0000-0002-4963-4667]
}

\author{
Mukachevo State University, Mukachevo, Ukraine \\ *tatyanak1815@gmail.com
}

\begin{abstract}
The article considers financial education as a set of theoretical knowledge, as well as the ability of the population to use their knowledge in practice, the essence of which is to effectively manage their finances, accounting for income and expenses, the ability to navigate the features of various financial products and services. Consumers around the world, especially vulnerable groups, have very limited knowledge of financial products and concepts. They also have problems making long-term sound financial decisions and choosing financial products that meet their needs. The improvement of financial literacy is facilitated by the actions of governments through the development and implementation of national financial education strategies. An empirical study of the relevance of financial education in Ukraine has been conducted. The results of the study showed that in Ukraine it is necessary to intensify activities to promote financial literacy and create mechanisms to ensure it through the creation of a system of education. Prospects for the development of financial literacy are seen in the fact that financial education should be provided and actively promoted at all stages of citizens' life on an ongoing basis; financial education programs should be clearly focused on the specific needs of citizens; consumers should receive educational services in the field of economics and finance as early as possible, starting with school; national authorities should consider including financial education in the compulsory school curriculum; educational programs of financial service providers must be legal, transparent and impartial. Particular attention should be paid to the fact that financial education should always serve the interests of the consumer.
\end{abstract}

Keywords: financial literacy, national strategy, educational perspectives.

\section{INTRODUCTION}

As a result of the financial crisis, more and more governments are developing targeted national strategies to improve the effectiveness of financial education through national coordination of targeted measures. National strategies are designed, in particular, to provide tailored solutions to meet citizens' financial literacy needs that use resources efficiently. There are more and more countries whose governments understand the longterm consequences of the low level of financial literacy of the majority of the population and feel the need to take the necessary measures. Simplified access for the middle class of emerging economies to basic financial products - bank accounts, loans, savings schemes - and complications of financial situation and services, amid cuts in social benefits and unemployment benefits in most developed countries highlighted the importance of decision-making on financial transactions by consumers.

Consumers around the world, especially vulnerable groups, have very limited knowledge of financial products and concepts. They also have problems making long-term sound financial decisions and choosing financial products that meet their needs, which can have adverse consequences not only for the future financial well-being of citizens, but also for the stability of the country's financial and economic system in the long run.

To address these challenges and empower consumers, governments and other stakeholders in many countries are developing financial literacy initiatives that complement financial consumer protection measures, financial regulatory reforms, and measures to improve access to financial services. Among these measures are educational activities that are currently considered the most effective. Such problems are emphasized by L. Honchar, S. Harna, A. Martynenko [1], T. Latkovska [2], S. Yurii , T. Kizima [3] and others. Relevant in essence are studies on the use of various innovative technologies, including information, such as the use of innovative technologies in teacher education courses [4], ensuring equality in education [5], teaching bookkeeping and 
learning models, models of knowledge content evolution [6 ], management of university courses [7].

\section{RESEARCH METHODOLOGY}

To achieve this goal, the following methods have been used: systematization of information on financial literacy in European countries; analysis and generalization of theoretical sources and statistical data in order to formulate the conclusions of the study, questionnaires to determine the features of the spread of financial literacy in Ukraine.

\section{RESEARCH RESULTS}

Financial literacy is a set of theoretical knowledge, as well as the ability of the population to use their knowledge in practice, the essence of which is to effectively manage their own finances, accounting for income and expenses, the ability to navigate the features of various financial products and services, to have up-todate information on the situation on the financial markets, to make informed decisions on financial products and services and to be responsible for such decisions [8].

Studies of the state of financial literacy in Ukraine show that about $65 \%$ of Ukrainians have an unsatisfactory level of financial awareness [8]. Among the main reasons for this situation are the following: almost $30 \%$ of citizens do not save at all, and those who do save, do it, saving their money for a "rainy day"; the majority of the population does not know how the financial institutions of the state work and what advantages they have; a large percentage of Ukrainians do not trust financial institutions and financial organizations; the population has only a general idea of their budget, i.e. they do not understand how to properly distribute their income and expenses; many are frightened by the huge number of risks and fear of losing the capital they have already acquired. The majority of the population uses only basic financial services, among them: payment of utility bills through a bank (72\%); use of bank account and plastic card $(68 \%)$; consumer credit $(30 \%)$; making payments through payment system terminals $(38 \%)$; money transfer through a bank $(92 \%)$; currency exchange (31\%) and other [9].

In the country with a relatively low income for Europe, it is income that is a decisive factor in the overall financial well-being of the population. But research suggests that for any income, welfare also influences people's behavior in relation to money (avoiding borrowing for everyday needs), their attitude (whether they focus on the short term and spending or on the long term and saving) and their financial knowledge. For example, the overwhelming majority of Ukrainians are much more focused on the short-term than on the longterm perspective and on spending than on savings [9, p.27].
Undoubtedly, the improvement of financial literacy is facilitated by the actions of governments through the development and implementation of national financial education strategies (for example, in Australia «National Strategy for Financial Literacy» [10], in Poland USAID FinRep "Financial Sector Development" [11] , in the Czech Republic - "National Strategy for Financial Education" (2010) [12].

The National Strategy for Financial Education is a state-coordinated approach to financial education, consisting of a platform or program adapted to specific conditions [13], which:

- recognize the importance of financial education including, perhaps, through the legislative system - and determine its content and scope at the national level, taking into account the identified needs and gaps of a particular country;

- involve the cooperation of various stakeholders, as well as the appointment of a national governing body or coordinating agency / council;

- determine the development plan - a system of measures aimed at achieving specific, predetermined goals within a specified period;

- contain instructions for use in individual programs in order to ensure an effective and appropriate contribution to the national strategy.

At the same time, in our opinion, it is important to form awareness of the importance of financial literacy, starting with primary education.

As the most progressive social group in Ukraine is teachers, our survey was conducted among primary school teachers of secondary schools in the Transcarpathian region, who have pedagogical education and carry out direct pedagogical activities (school teachers) - 78 people aged 18 to 40 .

Based on the results of our survey, we make a generalization that financial education is gaining relevance and popularity. The results of the survey show that, for example, in Ukrainian society the prevailing opinion is that increasing financial literacy is a necessary condition for the development of society $(72 \%)$, financial education should begin in primary school $(62 \%)$, using the potential of electives $(67 \%)$. At the same time, it is worth paying attention to the answers of the respondents regarding the assessment of their own financial literacy.

Thus, we can state that in Ukraine it is necessary to intensify activities to promote financial literacy and create mechanisms to ensure it. 
Table 1. Questionnaire results

\begin{tabular}{|c|c|c|c|}
\hline \multicolumn{1}{|c|}{ The content of the questionnaire } & $\begin{array}{c}\text { Yes } \\
\text { (number of } \\
\text { people) }\end{array}$ & $\begin{array}{c}\text { No } \\
\text { (number of } \\
\text { people) }\end{array}$ & $\begin{array}{c}\text { I can't answer } \\
\text { (number of } \\
\text { people) }\end{array}$ \\
\hline $\begin{array}{l}\text { Do you think that at the beginning of the XXI century the } \\
\text { increase of financial literacy is a necessary condition for the } \\
\text { development of society? }\end{array}$ & 56 & 10 \\
\hline $\begin{array}{l}\text { Do you think that financial education should start in } \\
\text { primary school? }\end{array}$ & 48 & 8 & 22 \\
\hline $\begin{array}{l}\text { Do you provide your schoolchildren with basic } \\
\text { knowledge about budget planning, saving money, using } \\
\text { ATMs, about the bank as a financial institution and more? }\end{array}$ & 36 & 36 \\
\hline $\begin{array}{l}\text { Do you think that it is necessary to introduce optional } \\
\text { classes on financial literacy in primary school? }\end{array}$ & 52 & 2 & 6 \\
\hline $\begin{array}{l}\text { Do you think that your level of financial literacy is high? } \\
\text { Do you currently need additional knowledge on budget } \\
\text { planning, saving money, opening a bank account, using } \\
\text { ATMs, as well as information on the security of payment } \\
\text { systems? }\end{array}$ & 60 & 46 & 24 \\
\hline
\end{tabular}

Do you currently need additional knowledge on budget planning, saving money, opening a bank account, using ATMs, as well as information on the security of payment systems?

Do you think that your level of financial literacy is high?

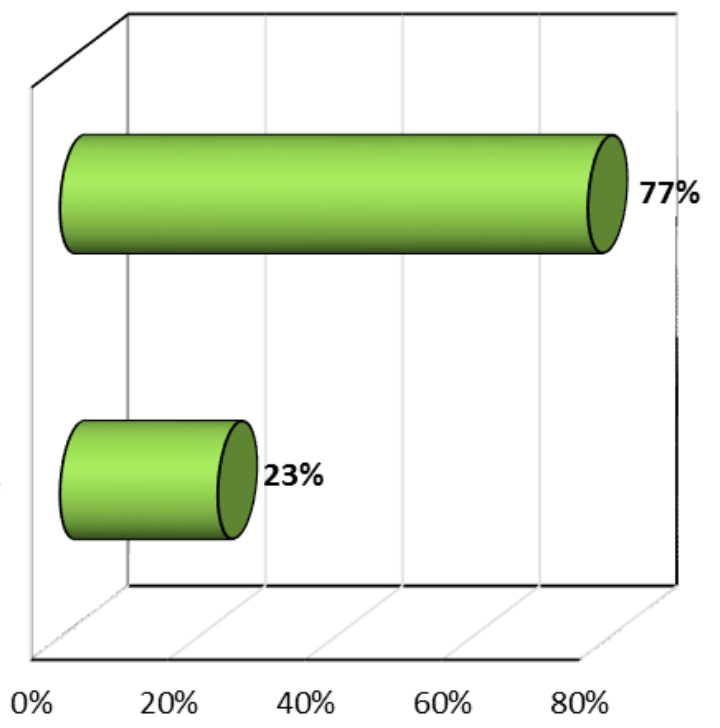

$\square$ Self-assessment of one's own financial literacy

Figure 1 The results of the questionnaire on self-assessment of teachers' own financial literacy

We see the prospects for the development of financial literacy in the fact that:

1. Financial education should be provided and actively promoted at all stages of citizens' lives on a regular basis.
2. Financial education programs should be clearly focused on the specific needs of citizens. To achieve this goal, preliminary research is needed to assess the current awareness of citizens in financial matters. In this way, it is possible to identify the most important problems that need to be addressed. 
3. Consumers should receive educational services in the field of economics and finance as early as possible, starting with school. Country leaders should consider integrating financial education into compulsory school curricula.

4. Educational programs of financial service providers must be legal, transparent and impartial. Particular attention should be paid to the fact that financial education should always serve the interests of consumers.

5. It is necessary to coordinate the work of stakeholders at the national level in order to clearly delineate functions, exchange experiences and rational and competent use of resources. Interaction between participants in the process at the international level also needs to be improved in order to create conditions for the exchange of best practices.

6. Providers of educational services in the field of finance should regularly evaluate and, if necessary, adjust work patterns that should be in line with best practices in this field.

7. Strengthening the effectiveness and stability of financial education policies and strategies by continuing to develop and record financial literacy data and effective ways of presenting financial education using available international instruments supported by the G20 governments (developed by the OECD / INFE and the World Bank [2012] and PISA in the field of financial literacy) [14].

8. Combining the roles of private and public stakeholders and long-term resource allocation for the successful implementation of national strategies.

9. Ensuring the quality of financial education by developing basic competencies and high standards of financial education services.

10.Deepening the dialogue on financial education at the international and regional levels, as well as establishing a dialogue with private companies, public organizations and the academic community in order to identify additional effective innovative solutions for implementation.

11. Practical expression of behavioral research (including available research on healthy lifestyles) and the impact of various (including innovative) consent instruments for detailed approaches to consumer protection and access to financial services, as well as the conceptual development of financial education initiatives and adapting them to the needs, abilities and preferences of the target audience.

\section{CONCLUSION}

Implementation of national measures to increase financial literacy of the population, taking into account the principles of the Organization for Economic
Cooperation and Development will help create favorable conditions for strengthening public confidence in the banking sector, increasing the inflow of funds into financial institutions, better understanding of financial instruments. As a result, the welfare of the population would increase, a financial culture would be formed, starting with school education and ending with the involvement of citizens in financial markets. Regulation of financial education should be carried out primarily at the state level on the basis of coordination and consolidation function (development of program goals and ways to achieve them; monitoring and analytical function) (accumulation of information on problem areas of financial services for the population), control and regulatory function agreements, timely provision of the legal framework), educational function (implementation of educational programs on financial literacy in educational institutions).

We see prospects for further research in the study of the problems of increasing the pedagogical potential of school economic education, increasing the status of economic training and financial literacy in school, information support for the implementation of financial education.

\section{REFERENCES}

[1] Honchar, L.V. Harna, S.O. and Martynenko, A.O. (2019), Financial literacy of the population of Ukraine as a factor of successful development of the state innovative economy, vol. 1-2 [78], pp. 182-186.

[2] Latkovska, T.A. (2013), "Increasing the level of financial literacy", Scientific works of the National University “Odessa Law Academy”, T. 13, S. 429438.

[3] Yurii, S.I. and Kizima, T.O. (2012), "Financial literacy of the population in the dialectic of modern educational trends", Finance of Ukraine, № 2, pp. 16-25.

[4] Ava Clare Marie O. Robles (2013), "The Use of Educational Web Tools: An Innovative Technique in Teacher Education Courses", IJMECS, vol. 5, no. 2, pp. 34-40. DOI: 10.5815 / ijmecs .2013.02.05

[5] Fengwu Zhang, Jin Tao (2013), "Research and Strategy of Educational Equity in the Context of the Harmonious Society", IJEME, vol. 3, no. 1, pp. 2126.

[6] Tadeusz Wibig and Punsiri Dam-o (2012), "The Model of the Evolution of the Knowledge Content and Contemporary Science Education Crisis", International Journal Modern Education and Computer Science, vol. 1, pp. 61-75, DOI: 10.5815 / ijmecs.2012.01.08 IJ 
[7] Ismail Aliyu, A. F. D. and Kana, Salisu Aliyu (2020), "Development of Knowledge Graph for University Courses Management", International Journal of Education and Management Engineering, vol. 10. no. 2. pp.1-10. DOI: 10.5815 / ijeme.2020.02.01

[8] Financial literacy and consumer protection: unnoticed aspects of the crisis: OECD Recommendation on Good Practice in Financial Education and Credit Knowledge, (2009), OECD, June, $20 \mathrm{p}$.

[9] Financial Literacy, Awareness and Inclusion in Ukraine: Research Report Additional IP-FSS Project in Ukraine: Regional Economic Development Project. 270 p., available at: https://old.bank.gov.ua/ doccatalog / document? Id = 83136332 (Access date 22.01.2021).

[10] Australia's National Financial Literacy Strategy (2011), Report of the Securities and Investment Commission of Australia, № 229.

[11] Financial literacy and consumer protection in Poland. Review on improving the level of financial literacy (2021), USAID FinRep Financial Sector Development Project, available at: www.financialeducation.org (Access date 22.01.2021).

[12] Narodni strategie financniho vzdelavani (2010), Ministerstvo finance, available at: http://www.mfcr.czcps/rde/ xbcr/mfcr /Narodni_strategie_Financniho_vzdelav (Access date 22.01.2021).

[13] OECD/INFE (2012), High-level Principles on National Strategy for Financial Education, available at: $\quad$ http://www.oecd.org/finance/financialeducation/OECD

INFE_High_Level_Principles_National_ Strategies_Financial_Education_APEC.p

[14] OECD (2016), The role of financial education in supporting decision-making for retirement, OECD Pensions Outlook, OECD Publishing, Paris. 